\title{
Perbandingan Perhitungan Harga Pokok Produksi Berdasarkan Metode Full Costing Vs Variable Costing Pada Produksi Sambel Pecel
}

\author{
Darno $^{\mathrm{a}, 1, *,}$, Liana Dwi Muasyaroh ${ }^{\mathrm{b}, 2}$ \\ a Universitas Maarif Hasyim Latif \\ b Universitas Maarif Hasyim Latif \\ ${ }^{1}$ darno@dosen.umaha.ac.id *; ${ }^{2}$ liana-dwi-muasyaroh@student.umaha.ac.id \\ * corresponding author
}

\section{ARTICLE INFO}

Article history

Received

Revised

Accepted

Keywords

Cost Of Production,

Full Cost Method, And

Variable Cost Method

\begin{abstract}
Manufacturing company is a company that processes raw goods into semifinished or finished goods. In manufacturing companies to determine the selling price does not escape from the calculation of the cost of production which is appropriate and in accordance with cost accounting standards. PT. Indramukti Segara is a fast food company that comes from natural ingredients. Products produced by PT. Indramukti Segara includes: pecel sauce and fried onions. Calculation of cost of goods manufactured by PT. Indramukti Segara is not right to determine the selling price, because the company only calculates the material used multiplied by the price of the material. On this occasion the author analyzes the cost of production in accordance with the Cost Accounting standard and conducts a comparison between two methods, namely: the full costing method and the variable costing method.

The purpose of this study is to compare the cost of production using the full cost and variable costs method. The data collected comes from the results of interviews with the Production Administration, Sambel Pecel production supervisor, and employees of Sambel production at PT. Indramukti Segara. Data obtained includes data on raw material expenditure, direct labor costs, and factory overhead costs that are fixed and variable. Based on the comparison of the calculation of Cost of Production between the full cost method and variable costs there are differences, because the full cost method calculates all costs that are fixed and variable while the variable cost method only calculates costs that are variable in nature.
\end{abstract}

\section{PENDAHULUAN}

\section{Latar Belakang}

Perusahaan manufaktur menjadi perusahaan yang berperan penting dalam mengendalikan perekonomian di Indonesia, karena perusahaan memberikan pendapatan yang besar kepada Negara melalui pajak atau kontrak lainnya. Besarnya perusahaan memberikan lapangan kerja sehingga angka pengangguran berkurang. Intput perusahan manufaktur yang berproduksi makanan antara lain: orang, bahan baku, tenaga kerja langsung, mesin produksi, tranportasi pemasaran, dan kantor. Output perusahaan makanan antara lain: hasil produksi, limbah produksi, dan polusi udara. Proses perusahaan makanan dimulai dari pemilihan bahan baku, pencucian bahan baku, pencampuran bahan baku dengan bahan penolong, proses paking, dan pemasaran. Siklus akuntansi biaya di perusahaan manufaktur dimulai dengan mencatat biaya bahan baku yang dimasukkan dalam proses produksi, diteruskan dengan pencatatan biaya tenaga kerja langsung, dan terakhir pencatatan biaya overhead pabrik. Proses ini memerlukan perhitungan harga pokok produksi untuk menentukan harga jual produk.

Harga pokok produksi adalah total biaya-biaya untuk mengolah bahan baku menjadi produk yang siap untuk dijual (Mulyadi, 2007:14). Untuk menghitung harga pokok produksi dapat menggunakan dua metode yaitu dengan menggunakan metode Full Costing dan metode Variable Costing. Kedua metode ini sama-sama menghitung biaya bahan baku, biaya tenaga kerja langsung, dan biaya overhead pabrik tetapi untuk metode full costing menggunakan biaya overhead tetap dan overhead variable sedangkan variable costing hanya menghitung beban overhead variable. 
Hal-hal yang berhubungan dengan harga pokok produksi antara lain: biaya bahan baku, biaya tenaga kerja, dan biaya overhead pabrik. Biaya bahan baku berperan besar dalam memproduksi barang setengah jadi maupun barang jadi oleh karena itu harus ada perencanaan dan pengendalian bahan baku untuk mengontrol kegiatan produksi. Hal seperti ini juga dilakukan oleh perusahaan makanan di PT. Indramukti Segara.

PT. Indramukti Segara yang beralamat di jalan raya Beringin Bendo KM. 2 nomer 22 Taman, Sidoarjo merupakan perusahaan yang mengolah makanan yang bersumber dari bahan alami, produk yang dihasilkan antara lain: bawang goreng dan sambel pecel. PT. Indramukti Segara dalam menghitung harga pokok produksi masih sangat sederhana yaitu dengan menghitung bahan yang dipakai dikalikan harga bahan.

\section{Tujuan Artikel}

Tujuan dari penelitian artikel ini:

1. Untuk mengetahui prosedur penentuan harga pokok produksi pada PT. Indramukti Segara.

2. Untuk mengetahui prosedur menghitung harga pokok produksi dengan menggunakan metode full costing.

3. Untuk mengetahui prosedur perhitungan harga pokok produksi dengan menggunakan metode variable costing.

\section{Penelitian terdahulu}

Niniek H. Samsul (2013), melakukan penelitian pada CV. Pyramid yang memperlihatkan perbandingan bahwa menghitung menggunakan metode full costing dengan variable costing. Dalam proses pengelompokan biaya, antara biaya nonproduksi dengan biaya overhead, perusahaan belum mengelompokan dengan baik sesuai jenisnya. Perbandingan menghitung dengan biaya penuh dan biaya fariabel dalam perhitungan HPP untuk penentuan harga jual perusahaan menunjukkan metode biaya penuh menunjukkan angka jauh lebih tinggi, karena dalam perhitungan harga pokok produksi pada metode biaya penuh mengakumulasikan semua biaya-biaya baik yang bersifat variabel maupun tetap.

\section{Cara menentukan biaya produksi}

Metode penentuan biaya produksi merupakan langkah dalam menghitung biaya-biaya ke dalam menentukan biaya produksi. Untuk menghitung biaya produksi, terdapat dua pendekatan yaitu: biaya penuh dan biaya variabel (Mulyadi, 2007:17).

1. Biaya Penuh adalah cara untuk menghitung harga pokok dari suatu produksi dengan cara menghitung semua biaya yang bersifat tetap maupun yang bersifat variabel.

\section{Tabel 3.1}

Penentuan Biaya Produksi

Metode biaya penuh

\begin{tabular}{|lc|}
\hline \multicolumn{2}{|c|}{ Metode biaya penuh } \\
\hline Biaya bahan utama & ---- \\
Biaya tenaga kerja langsung & ---- \\
Biaya penolong variabel & --- \\
Biaya penolong pabrik tetap & -----+ \\
Harga pokok produksi & ---- \\
\hline
\end{tabular}

2. Biaya Variabel adalah cara untuk menentukan harga pokok suatu produksi dengan cara menghitung biaya yang hanya bersifat varibel saja.

Tabel 3.2

Penentuan Biaya Produksi

Metode biaya variabel

Biaya bahan utama

Biaya tenaga kerja

Biaya penolong pabrik variabel

Harga pokok produksi 


\section{Harga pokok produksi}

Menurut (Mulyadi,2007:14), harga pokok suatu produksi merupakan total dari semua biaya dalam mengolahbahan baku menjadi produk yang siap untuk dijual.

Dari pendapat diatas, dapat dirangkum kalau harga pokok produksi adalah suatu pengeluaran biaya, yang terjadi untuk mendapatkan pendapatan jadi sebuah informasi tentang harga pokok produksi dapat menjadi acuan sebagai dasar menentukkan harga jual dari suatu produk selain sebagai dasar untuk menentukan kebijakan-kebijakan dalam mengolah perusahaan.

Tabel 3.3

Perhitungan Harga Pokok Produksi

\begin{tabular}{|c|c|c|}
\hline $\begin{array}{l}\text { Persediaan awal bahan baku } \\
\text { Pembelian bahan baku } \\
\text { Bahan baku barang tersedia untuk dijual } \\
\text { Persediaan akhir bahan baku } \\
\text { Pemakaian bahan baku } \\
\text { Upah langsung } \\
\text { Overhead pabrik } \\
\text { Jumlah biaya produksi } \\
\text { Persediaan awal barang dalam proses } \\
\text { Total barang dalam proses } \\
\text { Persediaan akhir barang dalam proses } \\
\text { Harga pokok produksi }\end{array}$ & $\begin{array}{r}\frac{\mathrm{XXX}}{\mathrm{Xxx}} \\
\mathrm{xxx} \\
\mathrm{Xxx} \\
\\
\mathrm{xxx} \\
\mathrm{xxx} \\
(\mathrm{xxx}) \\
\end{array}$ & $\begin{array}{r}\mathrm{xxX} \\
\mathrm{xxx}\end{array}$ \\
\hline
\end{tabular}

\section{Kerangka Konseptual}

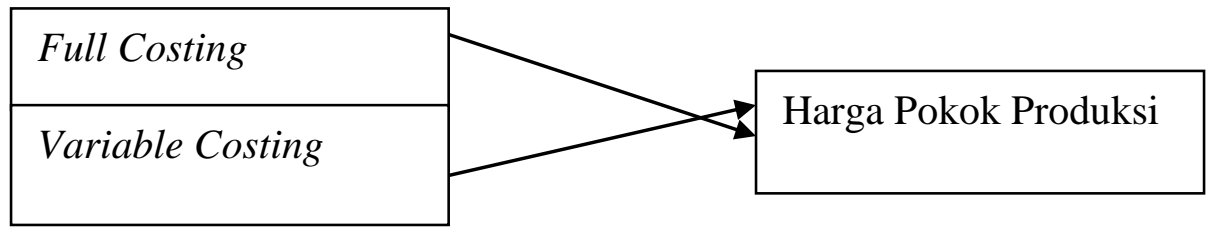

Keterangan Gambar:

Sangat penting dalam menghitung Harga Pokok Produksi untuk menentukan harga jual atau untuk menaikkan harga jual. Namun dalam menghitung harga jual perhitungan Hpp dapat menggunakan metode biaya penuh atau biaya variabel. Kedua cara ini sangat menentukan dalam menghitung harga pokok produksi. Setiap metode memiliki ketentutan dan perhitungan masing-masing, karena kedua metode ini berpengaruh terhadap harga pokok produksi.

\section{METODE}

Metode yang digunakan dalam penelitian ini menggunakan metode kuantitatif dengan pendekatan deskriptif. Metode deskriptif ini adalah metode untuk mendeskripsikan sebuah masalah dengan tujuan untuk mengetahui karakter dan hubungan antara dua variabel yaitu dengan cara mencermati ketentuan-ketentuan tertentu secara lebih spesifik untuk mendapatkan data sesuai dengan keadaan yang sesuai dengan tujuan penelitian, dimana data tersebut diolah, dianalisis, dan diproses lebih lanjut dengan dasar teori-teori yang telah di pelajari di dalam bangku kuliah sehingga dapat ditarik sebuah kesimpulan dari data tersebut.

\section{HASIL DAN PEMBAHASAN}

Dari hasil tanya jawab yang dilakukan oleh peneliti, kesimpulan dari wawancara terhadap ketiga narasumber tersebut memperlihatkan bahwa:

Pada PT. Indramukti Segara, perusahaan tersebut belum menggunakan medote perhitungan apapun. Sehingga untuk mengetahui harga pokok produksi PT. Indramukti Segara melakukan perhitungan bahan 
yang dipakai dikalikan harga bahan. Hal ini dirasa kurang efisien untuk mengetahui harga jual produk yang tepat.

Tabel 4.1 Biaya Bahan Baku Untuk tiga jenis produk

\begin{tabular}{|l|c|c|c|}
\hline Jenis bahan baku & Pecel 50 gram & Pecel 100 gram & Pecel 200 gram \\
\hline Kacang & $36.288 .000 / 8 \mathrm{~kg}$ & $36.288 .000 / 8 \mathrm{~kg}$ & $36,288,000 / 8 \mathrm{~kg}$ \\
\hline Gula & $15.120 .000 / 5 \mathrm{~kg}$ & $15.120 .000 / 5 \mathrm{~kg}$ & $15,120,000 / 5 \mathrm{~kg}$ \\
\hline Cabe besar & 1.176 .000 & 1.176 .000 & $1,176,000$ \\
\hline Cabe kecil & 12.432 .000 & 12.432 .000 & $12,432,000$ \\
\hline Asam & $4.334 .400 / 3 \mathrm{~kg}$ & $4.334 .400 / 3 \mathrm{~kg}$ & $4,334,400 / 3 \mathrm{~kg}$ \\
\hline Daun jeruk & $4.368 .000 / 4 \mathrm{~kg}$ & $4.368 .000 / 4 \mathrm{~kg}$ & $4,368,000 / 4 \mathrm{~kg}$ \\
\hline Kencur & $8.400 .000 / 2 \mathrm{~kg}$ & $8.400 .000 / 2 \mathrm{~kg}$ & $8.400 .000 / 2 \mathrm{~kg}$ \\
\hline Bawang putih & $4.704 .000 / 2 \mathrm{~kg}$ & $4.704 .000 / 2 \mathrm{~kg}$ & $4,704,000 / 2 \mathrm{~kg}$ \\
\hline Garam & $336.000 / 1 \mathrm{~kg}$ & $336.000 / 1 \mathrm{~kg}$ & $336,000 / 1 \mathrm{~kg}$ \\
\hline Total & $\mathbf{8 7 . 1 5 8 . 4 0 0}$ & $\mathbf{8 7 . 1 5 8 . 4 0 0}$ & $\mathbf{8 7 , 1 5 8 , 4 0 0}$ \\
\hline
\end{tabular}

Pada bulan November 2018 perusahaan telah mengeluarkan biaya bahan baku untuk tiga jenis produk pecel yaitu: kemasan 50 gram Rp 87.158.400, kemasan 100 gram Rp 87.158.400 dan kemasan 200 gram Rp 87.158.000.

Tabel 4.2 Biaya Tenaga Kerja Langsung untuk tiga jenis produk

\begin{tabular}{|l|c|c|c|}
\hline Uraian & Pecel 50 gram & Pecel 100 gram & Pecel 200 gram \\
\hline Jumlah produk & $252.000 \mathrm{~kg}$ & $126.000 \mathrm{~kg}$ & $65.520 \mathrm{~kg}$ \\
\hline Jumlah tenaga kerja & 5 orang (harian) & 29 orang (harian) & 21 orang (harian) \\
\hline Biaya tenaga kerja & $@ 119.000$ & $@ 119.000$ & $@ 119.000$ \\
\hline Total & Rp 1.855.000 & Rp 7.105.000 & Rp 3.874.920 \\
\hline
\end{tabular}

Sumber: PT. Indramukti Segara

Dengan jumlah nominal biaya tenaga kerja langsung untuk tiga jenis produk pecel kemasan 50 gram sebesar Rp 1.855.000, kemasan 100 gram sebesar Rp 7.105.000, dan kemasan 200 gram sebesar Rp 3.874.920.

Tabel 4.3 Biaya Overhead Pabrik untuk tiga jenis produk

\begin{tabular}{|l|c|c|c|}
\hline Uraian & Pecel 50 gram (Rp) & Pecel 100 gram (Rp) & $\begin{array}{l}\text { Pecel 200 gram } \\
(\mathbf{R p})\end{array}$ \\
\hline Biaya listrik: & & & $2.480 \mathrm{~V}$ \\
\hline Tegangan listrik & $2.240 \mathrm{~V}$ & $4.140 \mathrm{~V}$ & $8 \mathrm{jam}$ \\
\hline Waktu jam & $16.160 \mathrm{~V}$ & $33.120 \mathrm{~V}$ & $19.840 \mathrm{~V}$ \\
\hline & 4.091 .435 & 8.385 .417 & 5.023 .148 \\
\hline Total & 10.000 .000 & 30.000 .000 & 12.000 .000 \\
\hline $\begin{array}{l}\text { Reparasi dan } \\
\text { pemeliharaan mesin }\end{array}$ & 2.500 .000 & 63.000 .000 & 52.416 .000 \\
\hline Biaya plastik & 17.000 .000 & 17.000 .000 & 17.000 .000 \\
\hline $\begin{array}{l}\text { Biaya penyusutan } \\
\text { gedung pabrik }\end{array}$ & 25.000 .0000 & $40,000,000$ & 35.000 .000 \\
\hline $\begin{array}{l}\text { Biaya penyusutan } \\
\text { mesin dan peralatan }\end{array}$ & $\mathbf{5 5 . 8 6 3 . 7 3 3}$ & $\mathbf{1 5 2 . 7 9 4 . 9 7 9}$ & $\mathbf{1 1 8 . 0 9 0 . 2 8 7}$ \\
\hline Total & &
\end{tabular}

Sumber: PT. Indramukti Segara

Dengan jumlah nominal biaya overhead pabrik untuk tiga jenis produk pecel kemasan 50 gram sebesar Rp 55.863.733, kemasan 100 gram sebesar Rp 152.794.979, dan untuk kemasan 200 gram sebesar Rp 118.090.287. 
Tabel 4.4 Perhitungan harga pokok produksi bulan November 2018 pada PT. Indamukti Segara menurut metode Biaya Penuh

\begin{tabular}{|c|c|c|c|}
\hline Nama Biaya & Pecel 50 gram (Rp) & Pecel 100 gram (Rp) & Pecel 200 gram (Rp) \\
\hline \multicolumn{4}{|l|}{ Biaya Bahan Baku: } \\
\hline Kacang & $36.288 .00 / 8 \mathrm{~kg}$ & $36.288 .00 / 8 \mathrm{~kg}$ & $36.288 .00 / 8 \mathrm{~kg}$ \\
\hline Gula & $15.120 .00 / 5 \mathrm{~kg}$ & $15.120 .00 / 5 \mathrm{~kg}$ & $15.120 .00 / 5 \mathrm{~kg}$ \\
\hline Cabe besar & $1.176 .000 / 1 \mathrm{~kg}$ & $1.176 .000 / 1 \mathrm{~kg}$ & $1.176 .000 / 1 \mathrm{~kg}$ \\
\hline Cabe kecil & $12.432 .000 / 8 \mathrm{~kg}$ & $12.432 .000 / 8 \mathrm{~kg}$ & $12.432 .000 / 8 \mathrm{~kg}$ \\
\hline Asam & $4.334 .400 / 3 \mathrm{~kg}$ & $4.334 .400 / 3 \mathrm{~kg}$ & $4.334 .400 / 3 \mathrm{~kg}$ \\
\hline Daun jeruk & $4.368 .000 / 4 \mathrm{~kg}$ & $4.368 .000 / 4 \mathrm{~kg}$ & $4.368 .000 / 4 \mathrm{~kg}$ \\
\hline Kencur & $8.400 .000 / 2 \mathrm{~kg}$ & $8.400 .000 / 2 \mathrm{~kg}$ & $8.400 .000 / 2 \mathrm{~kg}$ \\
\hline Bawang Putih & $4.704 .000 / 2 \mathrm{~kg}$ & $4.704 .000 / 2 \mathrm{~kg}$ & $4.704 .000 / 2 \mathrm{~kg}$ \\
\hline Garam & $336.000 / 1 \mathrm{~kg}$ & $336.000 / 1 \mathrm{~kg}$ & $336.000 / 1 \mathrm{~kg}$ \\
\hline \multicolumn{4}{|l|}{$\begin{array}{l}\text { Biaya Tenaga Kerja } \\
\text { Langsung: }\end{array}$} \\
\hline T.K produksi & 1.855 .000 & 7.105 .000 & 3.874 .920 \\
\hline \multicolumn{4}{|l|}{$\begin{array}{l}\text { Biaya } \\
\text { Pabrik : }\end{array}$} \\
\hline Biaya listrik & 4.091 .435 & 8.385 .417 & 5.023 .148 \\
\hline $\begin{array}{l}\text { Reparasi dan } \\
\text { pemeliharaan mesin }\end{array}$ & 10.000 .000 & $30,000,000$ & 12.000 .000 \\
\hline Biaya plastik & 2.500 .000 & $63,000,000$ & 52.416 .000 \\
\hline $\begin{array}{l}\text { Biaya penyusutan } \\
\text { gedung pabrik }\end{array}$ & 17.000 .000 & $17,000,000$ & 17.000 .000 \\
\hline $\begin{array}{l}\text { Biaya penyusutan } \\
\text { mesin dan peralatan }\end{array}$ & 25.000 .0000 & $40,000,000$ & 35.000 .000 \\
\hline $\begin{array}{ll}\text { Harga } & \text { Pokok } \\
\text { Produksi } & \\
\end{array}$ & 147.604 .835 & 252.468.817 & 195.472 .468 \\
\hline \multicolumn{4}{|l|}{ Biaya non produksi } \\
\hline \multicolumn{4}{|l|}{$\begin{array}{l}\text { Biaya administrasi } \\
\text { dan umum: }\end{array}$} \\
\hline $\begin{array}{l}\text { Gaji karyawan adm } \\
\text { dan umum }\end{array}$ & $75,000,000$ & $75,000,000$ & 75.000 .000 \\
\hline $\begin{array}{ll}\text { Penyusutan } & \text { gedung } \\
\text { kantor } & \\
\end{array}$ & $15,000,000$ & $15,000,000$ & 15.000 .000 \\
\hline Macam-macam biaya & $35,000,000$ & $45,000,000$ & 45.000 .000 \\
\hline Gaji pemasaran & $35,000,000$ & $35,000,000$ & 35.000 .000 \\
\hline Total HPP & 317.604 .835 & 422.648 .817 & 365.472 .468 \\
\hline Jumlah produk & 252.000 & 126,000 & 65,520 \\
\hline $\begin{array}{l}\text { Total harga produk } \\
\text { per unit }\end{array}$ & $1.260,33664682$ & $3.354,3556904762$ & $5.578,0291208791$ \\
\hline $\begin{array}{l}\text { Pembulatan Harga } \\
\text { Produk Per Unit }\end{array}$ & 1.260 & 3.354 & 5.600 \\
\hline
\end{tabular}

Sumber: Data hasil olahan 2019

Hasil perhitungan menggunakan metode full costing dapat dilihat perbedaan jauh angka nominalnya dari tiga jenis produk. Bisa dilihat dari hasil perhitungan dengan metode full costing harga pokok produksi untuk pecel kemasan 50 gram adalah sebesar Rp 147.604.835 untuk pecel kemasan 100 gram adalah sebesar Rp 252.648.817 dan untuk pecel kemasan 200 gram adalah sebesar Rp 195.472.468. 
Tabel 5.4 Perhitungan Harga Pokok Produksi bulan November 2018 pada PT. Indramukti Segara Menurut Metode Biaya Variabel

\begin{tabular}{|c|c|c|c|}
\hline Nama Biaya & $\begin{array}{l}\text { Pecel } 50 \text { gram } \\
\text { (Rp) }\end{array}$ & $\begin{array}{l}\text { Pecel } 100 \text { gram } \\
\text { (Rp) }\end{array}$ & $\begin{array}{l}\text { Pecel 200 gram } \\
(\mathbf{R p})\end{array}$ \\
\hline \multicolumn{4}{|l|}{ Biaya bahan baku: } \\
\hline Kacang & $36.288 .00 / 8 \mathrm{~kg}$ & $36,288,000 / 8 \mathrm{~kg}$ & $36,288,00 / 8 \mathrm{~kg}$ \\
\hline Gula & $15.120 .00 / 5 \mathrm{~kg}$ & $15,120,000 / 5 \mathrm{~kg}$ & $15,120,00 / 5 \mathrm{~kg}$ \\
\hline Cabe besar & $1.176 .000 / 1 \mathrm{~kg}$ & $1,176,000 / 1 \mathrm{~kg}$ & $1,176,000 / 1 \mathrm{~kg}$ \\
\hline Cabe kecil & $12.432 .000 / 8 \mathrm{~kg}$ & $12,432,000 / 8 \mathrm{~kg}$ & $12,432,000 / 8 \mathrm{~kg}$ \\
\hline Asam & $4.334 .400 / 3 \mathrm{~kg}$ & $4.334 .400 / 3 \mathrm{~kg}$ & $4.334 .400 / 3 \mathrm{~kg}$ \\
\hline Daun jeruk & $4.368 .000 / 4 \mathrm{~kg}$ & $4.368 .000 / 4 \mathrm{~kg}$ & $4.368 .000 / 4 \mathrm{~kg}$ \\
\hline Kencur & $8.400 .000 / 2 \mathrm{~kg}$ & $8.400 .000 / 2 \mathrm{~kg}$ & $8.400 .000 / 2 \mathrm{~kg}$ \\
\hline Bawang Putih & $4.704 .000 / 2 \mathrm{~kg}$ & $4.704 .000 / 2 \mathrm{~kg}$ & $4.704 .000 / 2 \mathrm{~kg}$ \\
\hline Garam & $336.000 / 1 \mathrm{~kg}$ & $336.000 / 1 \mathrm{~kg}$ & $336.000 / 1 \mathrm{~kg}$ \\
\hline \multicolumn{4}{|l|}{$\begin{array}{l}\text { Biaya Tenaga Kerja } \\
\text { Langsung }\end{array}$} \\
\hline T.K produksi & 1.855 .000 & 7.105 .000 & 3.874 .920 \\
\hline \multicolumn{4}{|l|}{$\begin{array}{l}\text { Biaya Overhead } \\
\text { Pabrik Variabel }\end{array}$} \\
\hline Biaya plastik & 2.500 .000 & 63.000 .000 & 52.416 .000 \\
\hline Biaya listrik & 4.091 .435 & 8.385 .417 & 5.023 .148 \\
\hline $\begin{array}{l}\text { Reparasi dan } \\
\text { pemeliharaan mesin }\end{array}$ & 10.000 .000 & 30.000 .000 & 12.000 .000 \\
\hline $\begin{array}{ll}\text { Harga } & \text { Pokok } \\
\text { Produksi } & \end{array}$ & 105.604 .835 & 195.648 .817 & 160.472 .468 \\
\hline \multicolumn{4}{|l|}{ Biaya non produksi } \\
\hline \multicolumn{4}{|l|}{$\begin{array}{lll}\text { Biaya } & \text { adm } & \text { dan } \\
\text { umum: } & & \\
\end{array}$} \\
\hline Gaji adm dan umum & 75.000 .000 & 75.000 .000 & 75.000 .000 \\
\hline $\begin{array}{l}\text { Penyusutan gedung } \\
\text { kantor }\end{array}$ & 15.000 .000 & 15.000 .000 & 15.000 .000 \\
\hline Macam-macam biaya & 35.000 .000 & 35.000 .000 & 35.000 .000 \\
\hline Gaji pemasaran & 25.000 .000 & 25.000 .000 & 25.000 .000 \\
\hline Total HPP & 255.604 .835 & 345.648.817 & 310.472 .468 \\
\hline Jumlah produk & 252.000 & 126.000 & 65.520 \\
\hline $\begin{array}{l}\text { Total Harga Produk } \\
\text { PerUnit }\end{array}$ & $1.014,30490079$ & $2.742,24457936$ & $4.738,59078144$ \\
\hline $\begin{array}{l}\text { Pembulatan Harga } \\
\text { Pokok Per Unit }\end{array}$ & 1.014 & 2.742 & 4.700 \\
\hline
\end{tabular}

Sumber: Data Hasil Olahan 2019

Dari hasil perhitungan menggunakan metode biaya variabel dapat dilihat tinggi perbedaan angka nominalnya dengan perhitungan metode biaya penuh. Bisa dilihat, dari hasil perhitungan metode variable costing harga pokok produksi untuk kemasan pecel 50 gram adalah sebesar Rp 105.604.835, untuk kemasan pecel 100 gram adalah sebesar Rp 195.648.817 dan untuk kemasan pecel 200 gram adalah sebesar Rp 160.472 .468 .

\section{Kesimpulan}

Berdasarkan hasil penelitian yang dilakukan oleh penulis pada PT. Indramukti Segara, penulis banyak menemukan perbedaan perhitungan perusahaan dengan perhitungan penulis. Kesimpulan dari pembahasan yang telah diuraikan pada bab sebelumnya adalah sebagai berikut:

1. Perusahaan dalam menghitung harga pokok produksi dengan cara: bahan yang dipakai dikalikan harga bahan, yaitu 9 x Rp $174.700=\operatorname{Rp} 1.572 .300$. 
2. Perhitungan harga pokok produksi menggunakan metode full costing dengan menghitung biaya bahan baku + biaya tenaga kerja langsung + biaya overhead pabrik tetap dan variabel, yaitu: pecel kemasan 50 gram HPP $=$ Rp 147.604.835, pecel kemasan 100 gram Hpp $=$ Rp 252.468.817, dan pecel kemasan 200 gram HPP $=$ Rp 195.472.468.

3. Perhitungan harga pokok produksi menggunakan metode variable costing dengan menghitung biaya bahan baku + biaya tenaga kerja langsung + biaya overhead pabrik variabel, yaitu: pecel kemasan 50 gram HPP $=$ Rp 105.604.835, pecel kemasan 100 gram HPP $=\mathrm{Rp} 195.648 .817$, pecel kemasan 200 gram HPP $=$ Rp 160.472.468.

4. Perbandingan perhitungan harga pokok produksi antara metode full costing dengan metode variable costing adalah untuk pecel kemasan 50 gram Rp 147.604.835 : Rp 105.604.835 selisih Rp 42.000.000, pecel kemasan 100 gram Rp 252.468.817 : Rp 195.648.817 selisih Rp 56.820.000, pecel 200 gram Rp 195.472.468 : Rp 160.472.468 selisih Rp 35.000.000.

\section{Saran}

Saran yang dapat disampaikan oleh penulis berdasarkan hasil penelitian yang telah dilakukan adalah sebagai berikut:

1. Perusahaan sebaiknya memasukkan akun-akun biaya seperti biaya penyusutan gedung pabrik, biaya penyusutan mesin dan peralatan. Perhitungan harga pokok produksi dan penentuan harga pokok produk akan menjadi lebih tepat serta jumlah antara biaya overhead dan biaya nonproduksi tidak menurun dan tidak meningkat.

2. Penentuan harga pokok produksi sebaiknya menggunakan metode full costing, karena jauh lebih tepat apabila menentukan harga jual. Metode full costing memasukkan biaya produksi tetap dan biaya produksi variabel untuk menghitung harga pokok produksi.

3. Perhitungan menggunakan metode full costing, biaya produksinya tetap ada pada produk yang belum terjual dan tidak membebankan untuk kelangsungan bisnis pada periode selanjutnya.

\section{DAFTAR PUSTAKA}

Bastian, Bustami dan Nurlela.. 2009. Akuntansi Biaya. Edisi 1. Jakarta: Mitra Wacana Media.

Carter, William K. Akuntansi Biaya. Buku 1 Edisi 14. Jakarta: Salemba Empat.

Darno. 2019. Jurnal Pengendalian Harga Pokok Produksi Dengan Metode Full Costing Pada Kerupuk Sari Udang Mbah Oerip Sidoarjo.

http://scholar.google.co.id/Pengendalian_Harga_Pokok_Produksi_Dengan_Metode_Full_Costing_Pad a_Kerupuk_Sari_Udang_Mbah_Oerip_Sidoarjo. Diakses pada 28 Februari 2019.

Djumali, Indro. Sondakh, J.Jullie. Mawikere, Lidia. 2014. Jurnal Perhitungan Harga Pokok Produksi Menggunakan Variable Costing Dalam Penentuan Harga Jual Pada PT. Sari Malalugis Bitung. http://scholar.google.co.id/PerhitunganHargaPokokProduksiMenggunakanVariableCostingDalamPene ntuanHargaJualPadaPT.SariMalalugisBitung. Diakses pada 14 Maret 2019.

Komara, Bintang dan Sudarma,Ade. 2016. Jurnal Analisis Penentuan Harga Pokok Produksi Dengan Metode Full Costing Sebagai Dasar Penetapan Harga Jual Pada CV. Salwa Meubel.

http://scholar.google.co.id/Analisis_Penentuan_Harga_Pokok_Produksi_Dengan_Metode_Full_Costin g_Sebagai_Dasar_Penetapan_Harga_Jual_Pada_CV.Salwa_Meubel. Diakses pada 25 Februari 2019.

Kholmi, Masiyah dan Yuningsih. 2009. Akuntansi Biaya. Edisi Revisi. Malang: UMM Press.

Ma'arif, Rois. 2018. Laporan Praktik Kerja Nyata Penerapan konsep Akuntansi Biaya dalam menentukan Harga Pokok Produksi.

http://scholar.google.co.id/Laporan_Kerja_Nyata_Penerapan_Konsep_Akuntansi_Biaya_Dalam_Men entukan_Harga_Pokok_Produksi Diakses pada 12 Desember 2018.

Mulyadi.2015.Akuntansi Biaya. Edisi 5. Yogyakarta: UPT STIM YKPN.

Mulyadi. 2010. Biaya. Edisi 5. Yogyakarta: UPP STIM YKPN.

Mulyadi. 2009. Cara Penggolongan Biaya. Edisi 5. Yogyakarta: UPP STIM YKPN. 
Narafin. M. 2009. Penganggaran Perusahaan. Edisi 3. Jakarta: Salemba Empat.

Samsul, H. Niniek. 2013. Jurnal Perbandingan Harga Pokok Produksi Full Costing dan Variable Costing Untuk Harga Jual CV. Pyramid.

http://scholar.google.co.id/PerbandinganHargaPokokProduksiFullCostingdanVariableCostingUntukH argaJualCV.Pyramid. Diakses pada 14 Maret 2019.

Soleha, Halimatus 2016. Jurnal Analisis Perhitungan Harga Pokok Produksi Ayam Potong (Broiler) Dengan Metode Full Costing Pada Peternakan Abshar Mitra Usaha CV. Mutiara Abadi Samarinda. http://scholar.google.co.id/Analisis_Perhitungan_Harga_Pokok_Produksi_Ayam_(Broiler)_Dengan_ Metode Full Costing Pada Peternakan Abshar Mitra Kerja CV Mutiara Sinar Abadi Samarinda. Diakses pada 26 Februari 2019.

Supriyono,R.A.2000.Akuntansi Biaya. Edisi 2. Yogyakarta: BPFE UGM.

Sugiyono. 2017. Metode Penelitian. Bandung: Alfabeta. 